\title{
A universal primer for isolation of fragments of a gene encoding phytoene desaturase for use in virus-induced gene silencing (VIGS) studies
}

Article

Accepted Version

Yin-Chih, L., Imsabai, W., Reid, M. S., Cai-Zhong, J. and Wagstaff, C. (2010) A universal primer for isolation of fragments of a gene encoding phytoene desaturase for use in virus-induced gene silencing (VIGS) studies. Acta Horticulturae, 877. pp. 1697-1704. ISSN 0567-7572 Available at https://centaur.reading.ac.uk/18147/

It is advisable to refer to the publisher's version if you intend to cite from the work. See Guidance on citing.

Published version at: http://www.actahort.org/books/877/877_233.htm

Publisher: International Society for Horticultural Science

All outputs in CentAUR are protected by Intellectual Property Rights law, including copyright law. Copyright and IPR is retained by the creators or other copyright holders. Terms and conditions for use of this material are defined in the End User Agreement. 


\section{CentAUR}

Central Archive at the University of Reading

Reading's research outputs online 


\title{
A Universal Primer for Isolation of Fragments of a Gene Encoding Phytoene Desaturase for Use in Virus-Induced Gene Silencing (VIGS) Studies
}

\author{
L. Yin-Chih, W. Imsabai and M.S. Reid \\ Department of Plant Sciences \\ University of California \\ One Shields Avenue \\ Davis, CA 95616 \\ USA
}

\author{
C. Wagstaff \\ Food Biosciences Department \\ University of Reading, Whiteknights \\ PO Box 217, Reading \\ Berkshire, RG6 6AH \\ United Kingdom
}

\author{
J. Cai-Zhong \\ Crops Pathology and Genetic Research Unit \\ Agricultural Research Service \\ US Department of Agriculture \\ Davis, CA 95616 \\ USA
}

Keywords: $P D S$ (phytoene desaturase), VIGS (virus-induced gene silencing), TRV (tobacco rattle virus), PCR

\begin{abstract}
We have been using Virus-Induced Gene Silencing (VIGS) to test the function of genes that are candidates for involvement in floral senescence. Although VIGS is a powerful tool for assaying the effects of gene silencing in plants, relatively few taxa have been studied using this approach, and most that have are in the Solanaceae. We typically use silencing of phytoene desaturase (PDS) in preliminary tests of the feasibility of using VIGS. Silencing this gene, whose product is involved in carotene biosynthesis, results in a characteristic photobleaching phenotype in the leaves. We have found that efficient silencing requires the use of fragments that are more than $\mathbf{9 0 \%}$ homologous to the target gene. To simplify testing the effectiveness of VIGS in a range of species, we designed a set of universal primers to a region of the PDS gene that is highly conserved among species, and that therefore allows an investigator to isolate a fragment of the homologous PDS gene from the species of interest. We report the sequences of these primers and the results of VIGS experiments in horticultural species from the Asteraceae, Leguminosae, Balsaminaceae and Solanaceae.
\end{abstract}

\section{INTRODUCTION}

Virus-induced gene silencing (VIGS) is a method of transiently interrupting gene function through RNA interference. The VIGS process is a natural plant defense mechanism and is initiated experimentally by Agrobacterium-mediated introduction of viral genomes containing a fragment of a targeted plant gene. When the virus replicates and spreads in the infected plants, the plant cells recognize the foreign double-stranded chimeric RNAs synthesized during viral replication and cut them into small oligonucleotides (siRNA). The siRNA molecules that serve as guides for an RNAinduced silencing complex (RISC) that recognizes homologous gene transcripts (Baulcombe, 1999; Chicas and Macino, 2001) targeting them for hydrolysis and thereby reduces expression of the target gene.

VIGS provides a rapid method for loss of gene function assay, avoiding the need for time-consuming transformation and regeneration processes. In addition, VIGS provides the opportunity to overcome functional redundancy by suppressing all or most members of a gene family (Burch-Smith et al., 2004). Vectors based on tobacco rattle virus (TRV) with a wide host range have been shown to function effectively in Nicotiana benthamiana (Liu et al., 2002a), tomato (Liu et al., 2002b), petunia (Chen et al., 2004), 
poppy (Wege et al., 2007) and Aquilegia (Gould and Kramer, 2007) for phytoene desaturase $(P D S)$ silencing. Infected plants show characteristic photo-bleaching symptoms resulting from the decreased production of photoprotective carotenoid proteins and the subsequent breakdown of chlorophyll pigments. This phenotypic marker can be a potential reporter for examining the effect of silencing other target genes. In these previous studies, researchers reported that a highly homologous gene fragment was required to obtain high efficiency silencing. However, the sequence of PDS is not known for many species. In this paper, we describe a universal primer for isolation of PDS fragment from different plant species and report its successful use in a range of taxa.

\section{MATERIALS AND METHODS}

\section{Plant Material}

Seedlings of a range of species including petunia (Petunia $\times$ hybrida) 'Primetime Blue'; tomato (Lycopersicon esculentum) 'New Yorker'; Yesterday, today and tomorrow (Brunfelsia glandiflora); daisy 'Alaska'; gerbera (Gerbera $\times$ hybrida); chrysanthemum (Dendranthema grandiflorum) 'Veracruz'; lettuce (Lactuca sativa) 'Red Sails'; impatiens (Impatiens wallerana) 'Orange Bling'; Phalaenopsis orchid (Phalaenopsis amabilis); rose (Rosa × hybrida) 'Magnum'; four o'clock (Mirabilis jalapa); and bean (Phaseolus vulgaris) 'Kentucky Blue' and 'Golden Wax' were grown under 16h light/8h dark cycles at approximately $20-25^{\circ} \mathrm{C}$.

\section{Plasmid Construct}

PDS constructs: A 520 bp fragment of the PDS gene was amplified from leaf cDNA of each species using primers 5'-GGTGGAAAG (g/a) T (a/g/t) GCTGC (a/t/c) TGG-3' and 5'-GCCAT (t/c) TT (g/a/t) GAACCATG (t/c) TT (t/c) TCCTG-3'. The resulting product was cloned into pGEM-T easy (Promega) for amplification, sequencing and cloning. The PDS cDNA fragment was excised using EcoRI digestion from the plasmid, then subcloned into pTRV2 to generate a pTRV2 PDS construct specific to each species.

\section{Agrobacterium-Mediated Infection}

The constructs, pTRV1 (TRV RNA1 construct), and pTRV2 (RNA2 (empty vector control) or RNA2+PDS fragment) constructs were transformed into Agrobacterium strain GV3101 by electroporation. The bacteria were cultured overnight at $28^{\circ} \mathrm{C}$ in LB medium with $40 \mathrm{mg} / \mathrm{L}$ Kanamycin and $20 \mathrm{mg} / \mathrm{L}$ Gentamycin. The Agrobacterium cells were then harvested and resuspended in inoculation buffer $(10 \mathrm{mM} \mathrm{MgCl}, 10 \mathrm{mM}$ MES, $200 \mu \mathrm{M}$ acetosyringone) to an O.D. of $1 \sim 2$ and left at room temperature for at least $4 \mathrm{~h}$. The bacteria containing pTRV1 and the bacteria containing pTRV2 or pTRV2 PDS were mixed together in a 1:1 ratio. The leaves of seedlings were inoculated with the mixed bacteria culture using a $1 \mathrm{ml}$ disposable syringe without a needle (for daisy and tomato) or by vacuum infiltration (for lettuce and impatiens). Infected plants were incubated in growth chambers under $16 \mathrm{~h}$ light $/ 8 \mathrm{~h}$ dark cycles at the temperature of $20-22^{\circ} \mathrm{C}$.

\section{RT-PCR Analysis}

Total RNA was extracted from lettuce leaves using TRIzol Reagent (Invitrogen) and treated with RNase-free DNase (Ambion) to remove any contaminating genomic DNA. The first strand cDNA was synthesized using $2 \mu \mathrm{g}$ total RNA, oligo $\mathrm{d}(\mathrm{T})$ primer, random hexamer, and superscript reverse transcriptase (Invitrogen). This cDNA was normalized by real-time quantitative PCR using 18S rRNA primer (5'-CATGGCCGTTCTT AGTTGGTGGAG-3' and 5'-AAGAAGCTGGCCGCGAAGGGAT AC-3').

The primers for amplifying PDS transcripts by semi-quantitative PCR were designed outside the region targeted for gene silencing to avoid amplification from the pTRV PDS construct. These primers were 5'-CTTTGCAAGCCAATTGTTGA-3' and 5'TTGTAGGGGTCGACATGGTT-3'. 


\section{RESULTS AND DISCUSSION}

\section{Design of Primers to Amplify PDS Gene Fragments from Different Plant Species}

A BLAST search for PDS sequences from a wide range of taxa permitted us to design a set of degenerate primers that would amplify a PDS fragment from known species, and therefore, most probably from species where the gene's sequence is unknown. An approximately $520 \mathrm{bp}$ fragment of the $P D S$ gene was amplified by the degenerate primers from all tested species (Fig. 1). A comparison of the PDS fragment sequences from 9 different plant species reveals a similarity of higher than $80 \%$ but in most cases less than the $90 \%$ homology required for efficient VIGS (Fig. 2). It seems likely that most other species will include the highly conserved region of the PDS gene amplified by this pair of degenerate primers.

\section{Host Range of TRV-Induced PDS Gene Silencing}

Fragments isolated from the target species using our universal primers were very effective when used in VIGS silencing of PDS. Developing leaves of pTRV2-PDS infected plants showed the strong photobleaching phenotype that indicated movement of the virus and its effectiveness in silencing the native $P D S$ gene in bean, impatiens, daisy, and tomato (Fig. 3). No photo-bleached phenotype was found in the $\mathrm{H}_{2} \mathrm{O}$ or pTRV2 empty vector controls (data not shown).

$P D S$ gene transcripts were clearly evident in RNA extracted from non-silenced leaves and vector control, but barely detected in that from photo-bleaching leaves of lettuce by RT-PCR (Fig. 4). The result suggested that the photo-bleaching phenotype was caused by the down-regulation of the $P D S$ gene.

In previous VIGS studies of a wide range of different ornamentals (Chen et al., 2003), only N. benthamiana and P. hybrida (both from the Solanaceae) showed the PDS phenotype. We now suspect that this negative result reflected a lack of homology between the $P D S$ of $N$. benthamiana (the source of the PDS fragment used in the study) and the $P D S$ sequences in the other target species.

\section{Efficiency of VIGS in Different Species}

Although we were able to silence PDS in all of the species that we tested, efficiency (\% plants showing phenotype), and extent of silencing varied among taxa. Increasing the concentration of the Agrobacterium inoculum (to an $\mathrm{OD}_{600}$ of 2.0) increased the frequency of silencing in impatiens plants (Fig. 5). In most tested species, however, the silencing symptom was local, confined to one or two leaves (Fig. 3). To obtain systemic symptoms in such species, it may be necessary to develop techniques to improve viral movement, and/or inhibit the plant's antiviral mechanism.

\section{ACKNOWLEDGEMENTS}

We gratefully acknowledge the support of the American Floral Endowment, the USDA Floriculture Initiative, and the US-Israel Binational Agricultural Research and Development (BARD, IS-3815-05) and a BBSRC LINK grant in collaboration with Vitacress Salads Ltd. (CW).

\section{Literature Cited}

Baulcombe, D.C. 1999. Fast forward genetics based on virus-induced gene silencing. Current Opinion in Plant Biology 2:109-123.

Burch-Smith, T.M., Anderson, J.C., Martin, G.B. and Dinesh-Kumar, S.P. 2004. Applications and advantages of virus-induced gene silencing for gene function studies in plants. Plant Journal 39(5):734-746.

Chen, J.C., Jiang, C.Z., Gookin, T.E., Hunter, D.A., Clark, D.G. and Reid, M.S. 2004. Chalcone synthase as a reporter in virus-induced gene silencing studies of flower senescence. Plant Mol. Biol. 55:521-530.

Chen, J.C., Johnson, F., Clark, D.G., Gookin, T. and Reid, M.S. 2003. Potential 
application of virus-induced gene silencing (VIGS) in flower senescence studies. Acta Hort. 669:147-152.

Chicas, A. and Macino, G. 2001. Characteristics of post-transcriptional gene silencing. EMBO Reports 2:992-996.

Gould, B. and Kramer, E.M. 2007. Virus-induced gene silencing as a tool for functional analyses in the emerging model plant Auilegia (columbine, Ranunculaceae). Plant Methods 3:6.

Liu, Y., Schiff, M., Marathe, R. and Dinesh-Kumar, S.P. 2002a. Tobacco Rar1, EDS1 and NPR1/NIM1 like genes are required for N-mediated resistance to tobacco mosaic virus. Plant J. 30:415-429.

Liu, Y., Schiff, M. and Dinesh-Kumar, S.P. 2002b. Virus-induced gene silencing in tomato. Plant J. 31:777-786.

Wege, S., Scholz, A., Gleissberg, S. and Becke, A. 2007. Highly efficient virus-induced gene silencing (VIGS) in California poppy (Eschscholzia californica): An evaluation of VIGS as a strategy to obtain functional data from non-model plants. Annals of Botany 100:641-649.

\section{Figures}

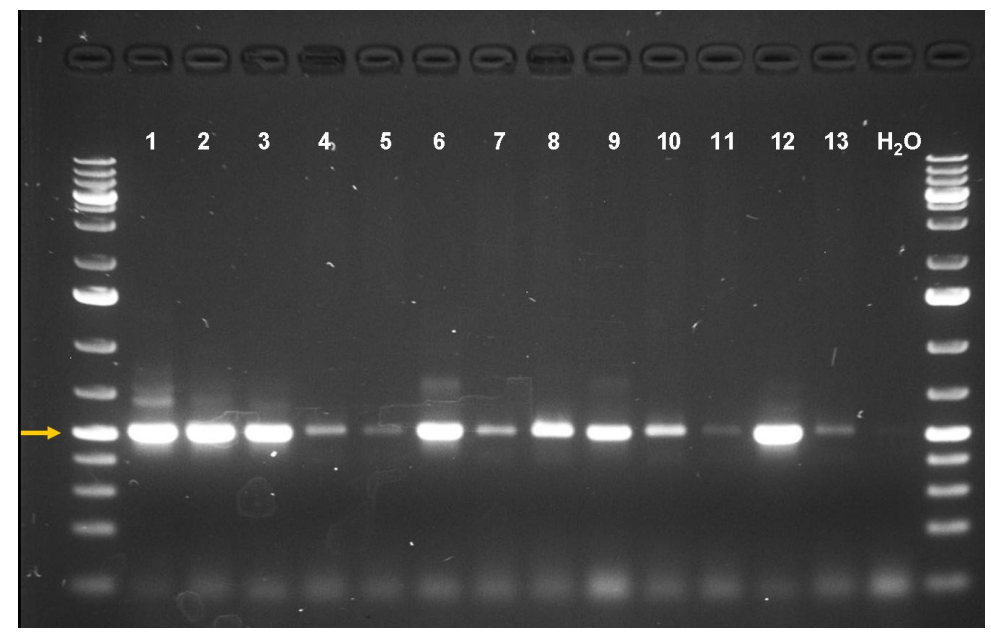

Fig. 1. $P D S$ gene fragments were amplified by the universal primers from different species. 1: Petunia; 2: Tomato; 3: Brunfelsia; 4: Daisy; 5: Gerbera; 6: Chrysanthemum; 7: Lettuce; 8: Impatiens; 9: Orchid; 10: Rose; 11: Mirabilis; 12: Pole bean; 13: Bush bean. The size of the PDS fragment is approximately $520 \mathrm{bp}$ (arrow). 


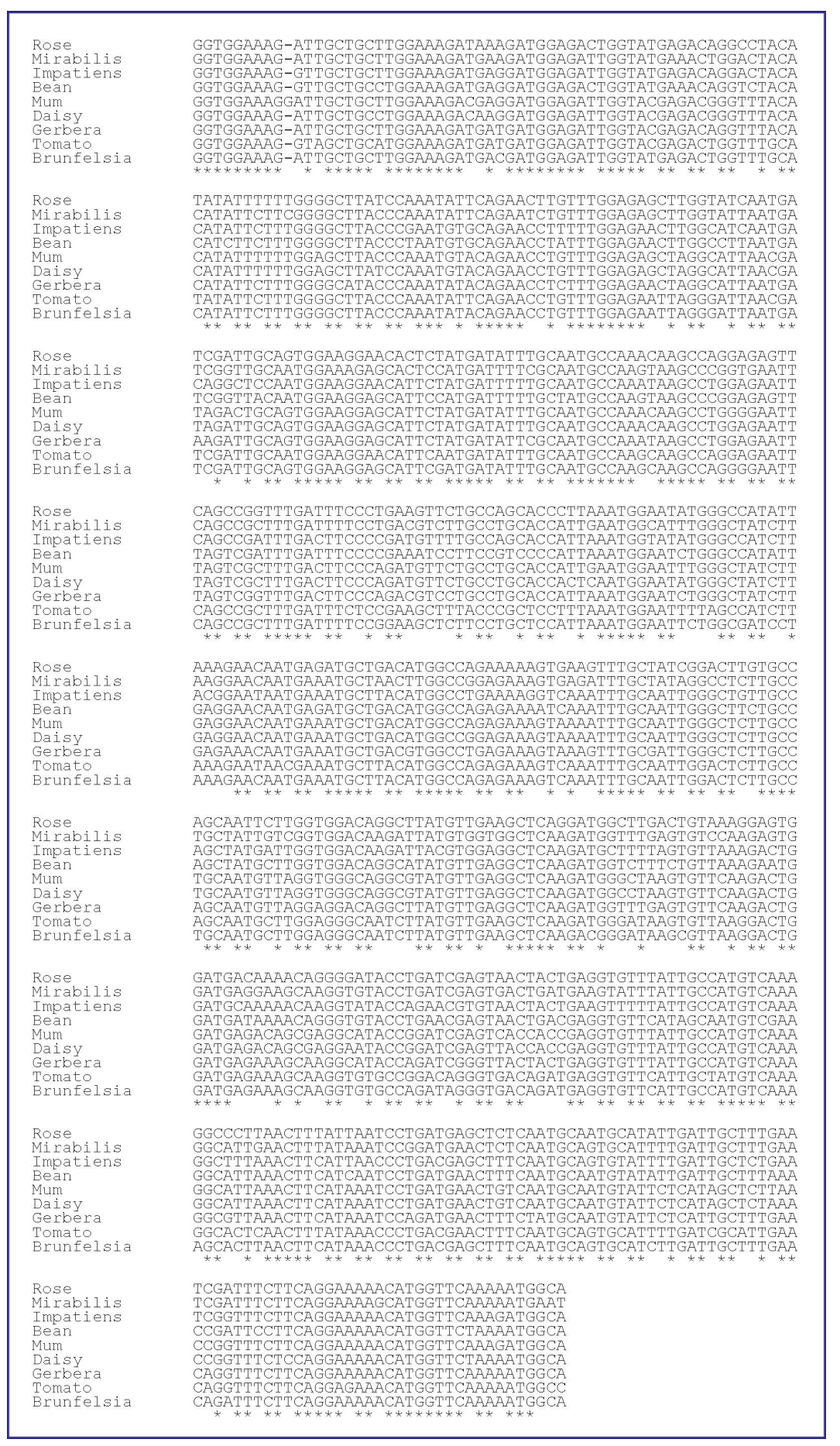

Fig. 2. Multiple sequence alignment of the $P D S$ fragments isolated from the 9 target plant species. 

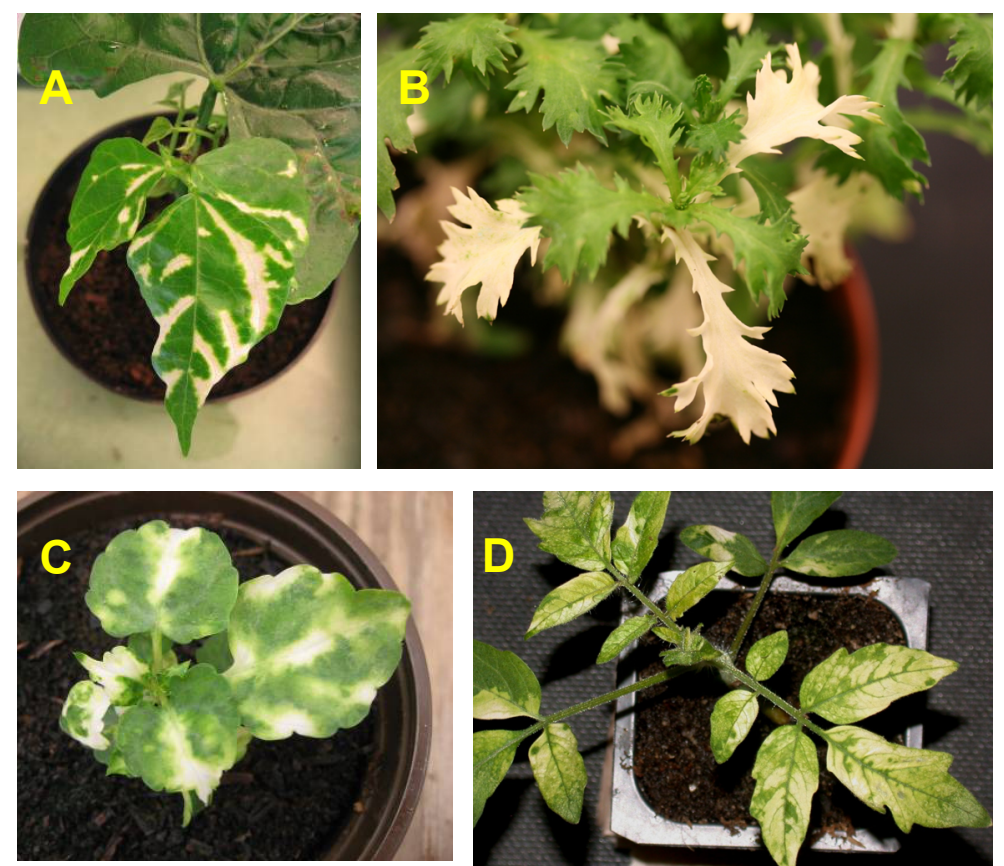

Fig. 3. Photobleaching phenotype resulting from VIGS silencing of $P D S$ in different plant species using fragments isolated with the universal primers. A: Henderson's Baby Bush Lima Bean, B: Daisy 'Alaska', C: Impatiens 'Orange Bling', D: Tomato 'New Yorker'.
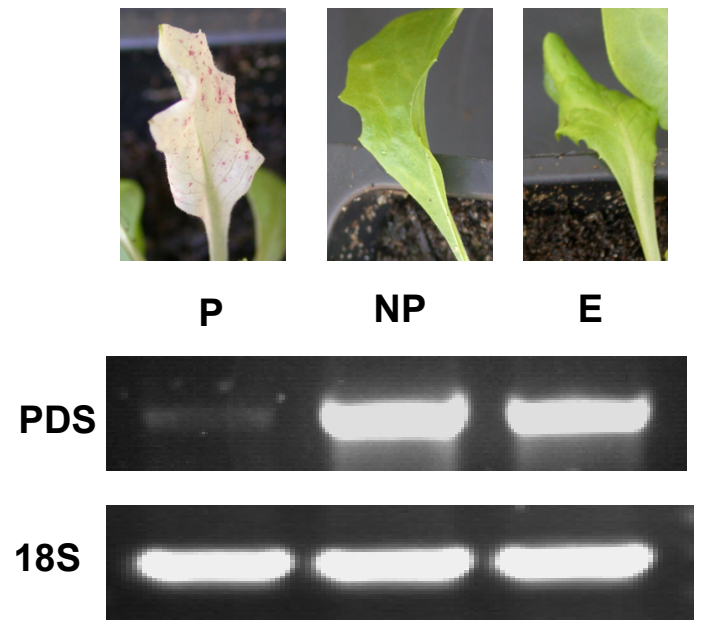

Fig. 4. Abundance of $P D S$ transcripts in 'Red Sails' lettuce plants after VIGS silencing. P-silenced tissue, NP-non-silenced tissue, E-empty vector control. 


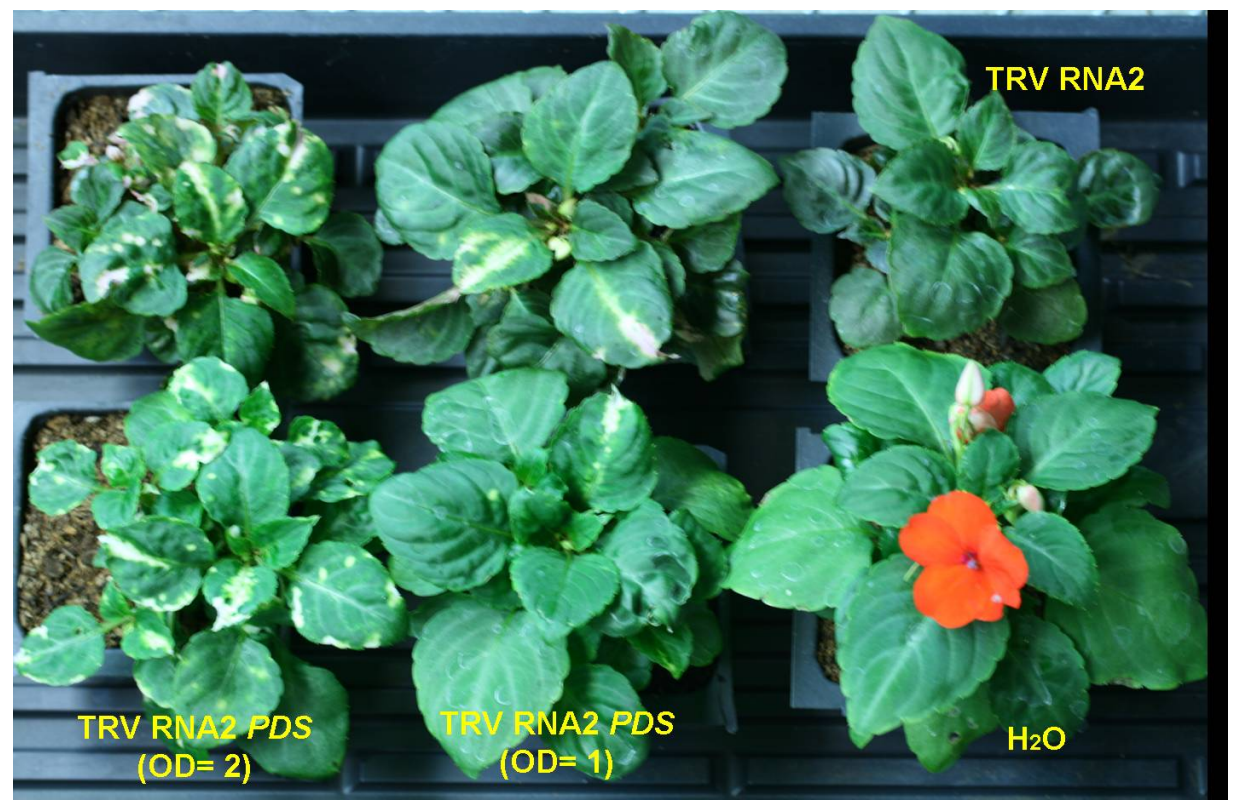

Fig. 5. Effect of Agrobacterium concentration on silencing PDS in impatiens plants. 
